\title{
The Structure of the Sarvadarśanasamgraha
}

\author{
Johannes Bronkhorst ${ }^{1} \oplus$
}

Accepted: 16 May 2021 / Published online: 21 June 2021

(C) The Author(s) 2021

\begin{abstract}
This article shows in detail that the widely held view according to which the Sarvadarśanasamgraha has a hierarchical structure is mistaken. It further argues that at least some parts of the texts were independent essays before being incorporated into the Sarvadarśanasamgraha.
\end{abstract}

Keywords Sarvadarśanasaṃgraha $\cdot$ Indian philosophy $\cdot$ Doxography

The Sarvadarśanasamgraha "Compendium of All Philosophies" was composed in the fourteenth century, in the South Indian empire of Vijayanagara. What happened to it during the next five centuries is not clear. No commentaries on it were written, as far as we know. Manuscript copies were made, but not in great abundance. No texts appear to quote the Sarvadarśanasamgraha or even refer to it until 1828, when H. H. Wilson's article "A sketch of the religious sects of the Hindus" mentions it and gives a brief enumeration of the schools of thought it deals with (pp. 10, 23).

A first printed edition of the Sarvadarśanasamgraha appeared between 1853 and 1858, and the text attracted henceforth more attention. An English translation (by E. B. Cowell and A. E. Gough) appeared between 1874 and 1878, and one of the translators "can hardly imagine a better guide for the European reader who wishes to study any one of these Darśanas in its native authorities". ${ }^{1}$ In subsequent years the Sarvadarśanasamgraha influenced early presentations of Indian philosophy. Max Müller's The Six Systems of Indian Philosophy (1899) refers to it regularly. And the part of Paul Deussen's Allgemeine Geschichte der Philosophie that deals with

\footnotetext{
${ }^{1}$ Cowell in Cowell and Gough $(1892$, p. ix).

Johannes Bronkhorst

johannes.bronkhorst@unil.ch

1 University of Lausanne, 1015 Lausanne, Switzerland
} 
India's systems of philosophy (Deussen, 1908, pp. 190-670) explicitly follows the lead of the Sarvadarśanasamgraha.

Depending on the edition one uses, the Sarvadarśanasamgraha has 15 or 16 chapters. Most manuscripts have only 15, but the edition most widely used (by Abhyankar and dating from 1923) has 16 of them. Here they are:

1. Materialism (cārvākadarśana).

2. The philosophy of the Buddhists (bauddhadarśana).

3. The philosophy of the Jainas (ärhatadarśana)

4. The philosophy of Rāmānuja (rāmānujadarśana)

5. The philosophy of Madhva (pūrnaprajñadarśana)

6. The philosophy of the Pāśupatas (nakulīśapāśspatadarśana)

7. The philosophy of the Śaivas (śaivadarśana)

8. The philosophy of Recognition (pratyabhijñädarśana)

9. Alchemy (raseśvaradarśana)

10. Vaiśeșika philosophy (aulūkyadarśana)

11. Nyāya philosophy (akșapādadarśana)

12. Pūrva-Mīmāṃsā philosophy (jaiminidarśana)

13. The philosophy of grammar (pāninidarśana)

14. Sāṃkhya philosophy (sāṃkhyadarśana)

15. Yoga philosophy (pātañjaladarśana)

16. Advaita-Vedānta (śänkaradarśana)

The last chapter, on the philosophy of Śankara, is missing in most manuscripts and in the early editions.

A number of modern authors claim that the Sarvadarśanasamgraha presents the various philosophies in hierarchical order. Cowell made this claim already in the 19th century in his Preface to the English translation he and Gough prepared: "The systems form a gradually ascending scale,- the first, the Chárváka and Bauddha, being the lowest as the furthest removed from the Vedānta, and the last, the Sánkhya and Yoga, being the highest as approaching most nearly to it" (Cowell \& Gough 1892, p. x.). Others repeated this claim in different words. Paul Deussen did so in 1908 (p. 191), Uma Shankar Sharma in 1964 (p. 5). Wilhelm Halbfass (1988, pp. 351-352) stated: "the Advaita Vedānta doxographic texts are usually based upon a hierarchical classification at whose apex stands the Vedānta. Here, the first (and lowest) system is materialism, which is presented as the school of Cārvāka or Lokāyata ..." His words are echoed by Eli Franco (2011, p. 640): "The Sarvadarśanasamgraha is the most important Sanskrit doxography. Its author Mādhava arranged 16 philosophical 'points of view' in a hierarchy in which the Cārvāka/Lokāyata is at the very bottom." Andrew Nicholson (2015, p. 165) says "there are no explicit characters or plot in the Sarvadarśanasamgraha, just a presentation of a series of doctrines, each superior to the last". 2 And the editor of The Bloomsbury Research Handbook of Vedānta adds ${ }^{3}$ :

\footnotetext{
${ }^{2}$ Nicholson is aware that his claim does not stand up to the facts (2015, p. 164): "Mādhava continues with this conceit for approximately the first eight chapters of his work, but he uses it less and less as its artificiality becomes more and more apparent. How does Vaiśeșika atomism function as the logical corrective to the Raseśvara Śaiva sect, for instance?"

${ }^{3}$ Maharaj (2020, p. 9).
} 
“The Advaitin Mādhava's ... highly influential Sarvadarśanasaṃgraha ... presented a hierarchical schema of sixteen philosophical schools beginning with the materialist philosophy of Cārvāka ... and culminating, predictably, in Advaita Vedānta." Other authors who made similar claims are Erich Frauwallner, ${ }^{4}$ Gerald Larson (2008, p. 282: "Altogether [Mādhavācārya] treats some sixteen systems in what appears to be a hierarchical manner"), Alberto Pelissero (2020) and Akihiko Akamatsu (Akamatsu 2017, p. 163: "Mādhava ... places his own school [Advaita] at one extreme and ranks other schools' teachings by their degree of conflict with his own system.") We may here also quote Robert Goodding's doctoral dissertation, which has not been published but is available on the internet (2002, p. 8): "His Sarvadarśanasamgraha is an arrangement of the various positions in Indian philosophy that Mādhava knew starting from the materialist Cārvākas and Buddhists that he thought had the least validity, up to the Pātañjalīya Yoga system and Śankkara's Advaita that is the highest expression of the truth."

An inspection of the text reveals that this understanding of the structure of the text is not supported by any evidence. Given that the highest truth finds expression in a form of Vedānta (Śankkara's Advaita Vedānta to be precise), we would expect that the philosophies of Rāmānuja and of Madhva, which are also forms of Vedānta, find a place near the end of the book. In reality they are discussed in chapters 4 and 5, far from the end. And the claim that Sāmkhya and Yoga-discussed in chapters 14 and 15 respectively_are close to Advaita Vedānta is not based on any statements in the Sarvadarśanasamgraha. On the contrary, these two philosophies are presented as the main representatives of a vision of the world, parināmavāda, that is the very opposite of the vivartavāda that Sankara adheres to. ${ }^{5}$ I'll return to this below. There is no trace of a hierarchy in the remaining chapters. ${ }^{6}$

How then could the idea of the Sarvadarśanasamgraha as a hierarchically structured text arise? I think that the way the text presents the first four philosophies -Materialism, Buddhism, Jainism and the school of Rāmānuja—goes some way to explain this misunderstanding. The philosophy of chapter 1 (Cārvāka) is refuted at the beginning of chapter 2 (Buddhism); the philosophy of chapter 2 is refuted at the beginning of chapter 3 (Jainism); the philosophy of chapter 3 is refuted at the beginning of chapter 4 (Rāmānuja). But there it stops. ${ }^{7}$ Chapter 5 (Madhva) does not refute chapter 4 , chapter 6 (Pāśupata) does not refute chapter 5, etc.

\footnotetext{
${ }^{4}$ Frauwallner (1992, p. 176): "Das glänzend geschriebene Werk gibt einen Überblick über alle philosophischen Systeme der damaligen Zeit, indem es mit dem tiefstehendsten, dem Materialismus, beginnt und nun, allmählich aufsteigend, jedes System durch das folgende widerlegen lässt, bis der Vedānta Śankaras, zu dem sich der Verfasser selbst bekennt, den Höhepunkt und Abschluss bildet.”

${ }^{5}$ Note that Sāmkhya and Yoga are sometimes described in other texts as unorthodox, i.e. not based on the Veda, as, e.g., in the Tantravārttika on sutra 1.3 .4 (p. 112 1. 17-24); translated Doniger O'Flaherty (1971, p. 276); cp. Eltschinger (2012, p. 56).

${ }^{6}$ Nor does the text of the Sarvadarśanasamgraha support the claim that "[f]or Mādhava, non-Advaitic schools were not so much wrong as they approximated, to varying degrees, the one perfect and absolutely true philosophy of Advaita" (Maharaja 2020, p. 9).

7 Strangely, Uma Shankar Sharma (1964, p. 5) states: "the Buddhists are shown refuting the epistemological theory of the Cārvākas. The Jainas, on the other hand, refute the theory of momentariness championed by the Buddhists. The Jaina doctrine of Anekāntavāda is refuted by the Rāmānujas and so on." There is no "and so on", in spite of Sharma's efforts to justify this on pp. 8-11.
} 
Suppose for a moment (contrary to the evidence) that each succeeding chapter does indeed refute the preceding one. Would this allow us to conclude that the structure of the Sarvadarśanasamgraha is hierarchical in the sense indicated above? Clearly, this conclusion would only be justified if this hierarchy were transitive. There is a priori no reason to think it is. The logic of the pecking order among chickens confirms this. This order, we learn, can be circular. That is to say, if chicken $\mathrm{A}$ is higher on the pecking order than chicken $\mathrm{B}$, and chicken $\mathrm{B}$ higher than chicken $\mathrm{C}$, this does not exclude that chicken $\mathrm{C}$ may be higher on the pecking order than chicken $\mathrm{A} .{ }^{8}$ The study of potential circularity in pecking orders goes back to $\mathrm{H}$. G. Landau (1953). It is related to the fact that the relation of dominance is not transitive: $\mathrm{A}$ is dominant over $\mathrm{B}$ and $\mathrm{B}$ is dominant over $\mathrm{C}$ does not necessarily entail that $\mathrm{A}$ is dominant over $\mathrm{C}$. The arguments used in chapter 2 to refute the philosophy of chapter 1 are not necessarily valid from the point of view of the philosophy of chapter 3; and the same might apply to all later chapters. Indeed, the arguments used in chapter 2 to refute the philosophy of chapter 1 are not valid from the point of view of Advaita Vedānta. To quote Nicholson (2015, p. 165): “This process is sometimes problematic, since the grounds by which the Buddhist disproves some Cārvāka theories are not acceptable to the Advaitin. A refutation of Cārvāka hedonism on the basis of the Buddhist doctrine of momentariness, for instance, is unacceptable, since Advaita does not accept that all entities in the world only exist for a moment before they pass out of existence."

There are other factors that weaken the thesis that hierarchy determines the sequence of chapters of the Sarvadarśanasamgraha. We have seen that this text contains a rejection of the doctrine of modification (parināmavāda) of Sāmkhya and Yoga in favor of the doctrine of illusory manifestation (vivartavāda). Vivartavāda is a feature of Śankara's philosophy but also of Bhartṛhari's philosophy as presented in chapter 13 ("Pāninin's philosophy"). Since the author of the Sarvadarśanasamgraha sides with Śankara, he must have preferred Bhartrhhari's thought to that of Sāmkhya. He should therefore have placed the chapter on Sāmkhya before the chapter on Pānini's philosophy. In fact he put it after that chapter. This is one more reason to abandon the idea that the chapters of the Sarvadarśanasamgraha are ordered in a hierarchical manner.

More than 60 years ago Minoru Hara (1958, p. 11) made the following observation: "It seems to me likely that what can be shown of the Nakuliśapāśupata-darśana will be found true of the other chapters of Sarvadarśanasamgraha also. That is, it was Mādhava's practice to take two or three basic texts of the system, quote a number of their basic definitions word for word, summarize a number of secondary doctrines in a manner as close to the original as brevity would permit and then embox the whole between an introductory paragraph and a concluding summary."

Hara's observation suggests that the different chapters of the Sarvadarśanasamgraha are more or less independent of each other, that they contain little essays dealing with the philosophies concerned. In fact, his observation is valid for a number of chapters, but not for others. It primarily fits the chapter that Hara

\footnotetext{
${ }^{8}$ See on all this Strycker (2014, 145 ff.) ("Seeing red: When the pecking order breaks down").
} 
translated (chapter 6), but also the immediately following chapters 7, 8 and 9, which, like chapter 6 , deal with the views of various followers of Śiva. These chapters are very little "philosophical" in the sense that they almost completely lack justifications and avoid debates. They look like independent essays that could have been produced, and published, on their own. They raise the question whether all chapters must be looked upon as potentially independent treatises, so that the Sarvadarśanasamgraha is really a collection of independent essays, some of them minimally adjusted so as to fit into the whole.

With this in mind, let us look at the chapter on Sāṃkhya (Chap. 14). This chapter begins with a question: "How can we respect the doctrine of the illusory manifestation (vivartavāda) in view of the doctrine of modification (parināmavāda) propounded by the Sāmkhyas, which is its watchful enemy (paripanthin)?"9 This is an unusual beginning. It implicitly criticizes a central feature of Sāmkhya philosophy-parināmavāda-even before its presentation. This shows that at least this chapter is more than an independent essay on the philosophy concerned. A closer look at the text reveals that the chapter on Sāmphya is not independent at all.

The chapter on Sāmkhya does not answer the question raised at its beginning. It consists, as a matter of fact, of a brief presentation of the existents accepted in Sāmkhya followed by a detailed discussion of the proofs that justify these. The question raised at the beginning is not answered in the then following chapter on Yoga (Chap. 15) either. It is answered at the beginning of chapter 16, on Śankara's philosophy. This chapter begins: "This doctrine of modification (parināmavāda) should be censured by those who follow valid means of cognition (prāmānika)."10 In fact, the first 63 lines (out of 918) of this chapter are nothing but a detailed refutation of the arguments in favor of parinamavāda that had been given in the chapter on Sāmkhya, explicitly referring back to passages of that chapter. ${ }^{11}$ They do not refer back to the chapter on Yoga. They conclude with the observation that, for all the reasons given, parināmavāda must be abandoned; instead, vivartavāda must be accepted. ${ }^{12}$ To end it all, they quote a verse by Vācaspati that states that this manifold is an illusory manifestation (vivarta) of Brahma, who does not undergo modification (aparin̄āmin). ${ }^{13}$

It seems clear that the chapter on Sāmkhya (Chap. 14) along with the first 63 lines of chapter 16 once constituted a unit, in which a presentation of Sāmkhya is emboxed by passages that criticize its central doctrine: the parināmavāda. This unit contained a detailed presentation and subsequent refutation of that doctrine. ${ }^{14} \mathrm{We}$ shall refer to it as the "Presentation and Refutation of parināmavāda". To all

\footnotetext{
${ }^{9}$ P. 311 11. 14.1-2: atha sāṃkhyair ākhyāte parināmavāde paripanthini jāgarūke kathaṃkāram vivartavāda ādaran̄īyo bhavet. Unless otherwise indicated, references are to Abhyankar's edition.

${ }^{10}$ P. 389 1. 1: so 'yam parịnāmavādah prāmāṇikagarhaṇam arhati.

11 For details, see Bronkhorst (forthcoming).

12 P. 393 11. 54-55: tasmāt parināmah parityaktavyah̆/ svīkartavyaś ca vivartavādah/.

13 P. 393 11. 61-62: vivartas tu prapañco 'yam brahmaṇo 'parināminah/ anādivāsanodbhūto na sārūpyam apekșate/l.

14 It is not impossible that the final line of chapter 14, which characterizes Sāṃkhya as nirīśvara and thus introduces the following chapter on seśvarasāmkhya (Yoga), was added.
} 
appearances, it was once a separate text, whose purpose was to analyze and reject the parinammavāda. As we have seen, it says so at the beginning and repeats it at the end.

This text, to repeat it once more, contained a presentation of the Sāmkhya philosophy (as the embodiment of parināmavāda), followed by its refutation. It appears that the author of the Sarvadarśanasamgraha, whoever he was, chose the Presentation for his chapter on Sāṃkhya, with no or few changes (he did not remove the initial question that allows us to reconstruct what happened). However, he separated the Presentation from the Refutation by inserting a chapter on Yoga in between, with the following result: a Presentation of Sāmkhya (the main embodiment of parinamavāda), followed by a presentation of Yoga, followed in its turn by a Refutation of parin̄āmavāda. The presentations of Sāmkhya and Yoga became chapters of the Sarvadarśanasamgraha (chapters 14 and 15 respectively); the refutation/Refutation of parināmavāda could not be part of these chapters, and followed, after the exposition of Yoga.

Here, then, we have a case where the author of the Sarvadarśanasamgraha appears to have used a pre-existing unit of text and incorporated it in his book. ${ }^{15} \mathrm{He}$ used most of this unit in his chapter on Sāmkhya. What remained he put in the one but next chapter. In between these two parts, he inserted a long chapter on Yoga.

At this point we are confronted with a difficulty. As I pointed out above, most manuscripts of the Sarvadarśanasamgraha have only 15 chapters. Chapter 16, on Śankara's philosophy, is missing in these manuscripts. And chapter 15, on Yoga, ends with the following sentence ${ }^{16}$ :

\section{itah parạ̣ sarvadarśanaśiromaṇibhūtam śāinkaradarśanam anyatra likhitam ity atropekșitam iti}

The philosophy of Śankara, which comes hereafter and is the crest-jewel of all philosophies, has been described elsewhere and is therefore here left out.

This suggests that there was an independent text expounding Śankara's philosophy that subsequently came to be incorporated into the Sarvadarśanasamgraha as chapter 16. This, however, is impossible. Chapter 16 is not an independent text on Śankara's philosophy, because its first 63 lines are a direct response to the chapter on Sāmkhya. If there was an independent text on Śankara's philosophy (and there is no reason to doubt this), ${ }^{17}$ it may have been the part of chapter 16 that begins with line 64; it cannot have been the whole chapter. The first 63 lines of this chapter were not part of it. What is more, these 63 lines were inseparably connected with the preceding chapters, more precisely: with chapter 14.

\footnotetext{
15 Pre-existing does not necessarily mean that it had a different author; this question must remain open for the moment.

16 Mysteriously, Abhyankar's manuscript D-which appears to be the only one he used that contained Chap. 16 as we find it in his edition-has the sentence itah param ... at the end of Chap. 15. (The indications provided by the Ānandāśrama edition are not clear enough to draw conclusions about the manuscripts it used.) This is mysterious, for what could be the point of announcing that there will be no chapter on Śankara's philosophy just before the beginning of the chapter on Śankara's philosophy?

17 Once again, independent does not necessarily mean that it had a different author; see foot note 15 above.
} 
This leaves us with a problem for which I have no unambiguous solution. It seems certain that the early textual tradition of the Sarvadarśanasamgraha went through an obscure period out of which two manuscript traditions arose. Most manuscripts had only 15 chapters; in the process they had removed the 63 lines that should have been inseparable from what preceded. A minority of manuscripts added the treatise on the philosophy of Śankara, but in doing so preserved those very same 63 lines that the other manuscripts had lost or discarded.

Note that these reflections are not based on a study of the surviving manuscripts of the Sarvadarśanasamgraha, but only on the manuscript-based editions of that text. A study of all the surviving manuscripts may throw more light on the questions here raised. Or it may not. It seems however clear that, at least in the case of his treatment of Sāmkhya, the author of the Sarvadarśanasamgraha made use of an independent unit of text, which he felt free to split into two and details of which he may have modified. Also the content of chapter 16 (on Śankara's philosophy), with the exception of its first 63 lines, was once an independent unit, as is clear from the line (quoted above) that concludes the manuscripts that have only 15 chapter. These two units, as we have seen, did not coincide with chapters of the Sarvadarśanasamgraha: the unit on parināmavāda ended up in two different chapters (Chaps. 14 and 16), and the unit on Śankara's philosophy makes up part of Chap. 16.

Can we identify more units that do not coincide with chapters? We saw that some philosophies are refuted in the chapters that follow them. The chapter on Jaina philosophy (Chap. 3), for example, is followed (not preceded!) by its refutation. This refutation is part of the following chapter, on Rāmānuja's philosophy (Chap. 4; p. 89 1l. 4.1-31), even though the refutation has little or nothing to do with Rāmānuja's philosophy (the name Rāmānuja does not occur until its very last line, 1 . 4.32). In other words, this refutation can be read as an appendix to the preceding chapter, just as the Refutation of parināmavāda was presumably an appendix to the two preceding chapters, on Sāmkhya and Yoga respectively. The beginning of the chapter on Jaina philosophy (Chap. 3; p. 48-55 11. 3.1-69), similarly, contains a long refutation of the Buddhist philosophy that had been the subject matter of the preceding chapter (Chap. 2). This time the Jaina identity of this refutation is clear: it refers to Jaina doctrines. It is yet not part of the regular presentation of Jaina doctrine, which begins at line 3.69 and extends up to the end at line 3.438. The same can be said about the beginning of the chapter on Buddhist philosophy (Chap. 2; p. 16-19 11. 2.1-40), which refutes the philosophy of Cārvāka, the subject matter of the preceding chapter (Chap. 1). This refutation is explicitly stated to come from Buddhists.

I see no reason to believe that the presentation of these philosophies along with their refutations ever constituted independently existing units. The refutations in these cases, as far as we can tell, were composed by the author of the Sarvadarśanasamgraha while he created his work. Their presence in the text raises however another question: why are only certain philosophies refuted, while others are not?

The philosophies that are refuted are Materialism, Buddhism, Jainism and Sāmkhya. None of the others are. It is true that some of the other chapters contain 
polemical passages. The chapters on the philosophies of Rāmānuja and Madhva, for example, contain extensive criticism of Advaita Vedānta. Some other chapters criticize more or less in passing certain differing views. But only Materialism, Buddhism, Jainism and Sāṃkhya (which includes Yoga; both Sāṃkhya and Yoga are forms of parin̄amavāda) are explicitly rejected. Why only these?

I can think of only one answer. The author of the Sarvadarśanasamgraha looked upon these, and only these, philosophies as in some sense "unorthodox". All the other philosophies were somehow considered "orthodox" and not therefore in need of refutation.

Perhaps this division into "orthodox" and "unorthodox" is not surprising. Materialism, Buddhism and Jainism are the eternal opponents of Brahmanical thinkers throughout much of Indian intellectual history. The critical attitude of Sāmkhya toward the Vedic sacrifice would explain that this philosophy, too, is "unorthodox". 18

Seen this way, we must distinguish two kinds of philosophies in the Sarvadarśanasamgraha: some are "orthodox", others "unorthodox". And even though some of the "unorthodox" philosophies occur at the beginning of the text, the presence of the two kinds of Sāmkhya near its end shows that the schools are not hierarchically ordered.

Our pair "orthodox"- "unorthodox" brings to mind the pair āstika-nāstika. These terms are sometimes paraphrased in modern scholarship as "orthodox or Brahmanical" and "heterodox or Śramanic" respectively (Aklujkar 2017, p. 43). Indeed, "Those according to whom the other world spoken of by the Veda exists are ästikas. The rest are nāstikas." ${ }^{19}$ Wilhelm Halbfass (1988, pp. 352-353), similarly, presented nāstika as more or less synonymous with avaidika, and āstika with vaidika.

Certain authors believe that the pair āstika-nāstika appropriately describes how the Sarvadarśanasamgraha categorizes its philosophies. Andrew Nicholson (2012, pp. 107-108), for example, contrasts the use of āstika and nāstika in Haribhadra's Saddarśanasamuccaya with that in the Sarvadarśanasamgraha:

For Haribhadra, the six āstika schools are: Buddhism, Nyāya, Sāṃkhya, Jainism, Vaiśeșika and Mīmāṃsā. ... Haribhadra ... [includes] Buddhism and Jainism. Haribhadra does this by defining the term asstika differently than it is understood by Mādhava or Madhusūdana.

For Haribhadra-Nicholson adds (p. 108)—only one school is nāstika, viz. "the materialist Lokāyata school".

\footnotetext{
18 Chakravarti (1951, p. 4 ff.).

19 Aklujkar (2017, p. 45) ascribes these words to Vasudeva Shastri Abhyankar, without giving a precise reference. I do not find any mention of the "other world" in the relevant passages of Abhyankar's introduction (upodghāta) to his edition of the Sarvadarśanasamgraha. We read there: śrutiprāmānyāvirodhinas tārkikaviśeșā āstikāh (p. 47) and śrutiprāmānyavirodhinas tārkikaviśeșā nāstikāh (p. 48)
} 
Though mentioning Mādhava in the above quote, Nicholson says very little about his Sarvadarśanasamgraha, ${ }^{20}$ concentrating rather on the works of Madhusūdana Sarasvatī. This leaves his claim that the Sarvadarśanasamgraha understands the term astika differently than Haribhadra dangling in the air. In fact, the Sarvadarśanasamgraha never uses the word āstika, and it uses the word nāstika only twice. An inspection of its use of nastika leads to a surprising result.

The first occurrence of nāstika in the Sarvadarśanasamgraha is on p. 2 (1. 1.14), at the very beginning of the discussion of the "philosophy of Cārvāka". Here Cārvāka is called nāstikaśiromaṇi "the crest-jewel of the nāstikas". Since the philosophy of Cārvāka is also known by the name Lokāyata (also in the Sarvadarśanasamgraha), ${ }^{21}$ we may conclude that this text agreed with Haribhadra in looking upon the followers of this school as nāstikas.

The word nāstika occurs a second time on p. 255 (1. 11.204), once again as part of the compound nāstikaśiromaṇi, this time in the chapter on the philosophy of Akșapāda (= Nyāya). The compound occurs in a debate about whether God (íśvara) created the world or not. The opponent, who is not specified, argues that it just does not do to assume that God created the world, one reason being that God could have no ground to create it for himself, and that, if He created it out of compassion for others, there would be no suffering in the world. The opponent concludes this passage with some quoted lines that he attributes to "teacher Bhața" (bhatțācārya) and that can be found in almost identical form in Kumārila Bhațta's Ślokavārttika. ${ }^{22}$ Immediately following this quotation, the proponent gives an answer that begins with the vocative nāstikaśiromane "Oh crest-jewel of the nāstikas!"

What these two passages suggest is that the author of the Sarvadarśanasamgraha used the expression nāstika for all those who deny the existence of God, or at any rate His role in the creation of the world. This would then include the school of Mīmāṃsā. This would be noteworthy, since Mīmāṃsā is often thought of as a bulwark of Brahmanical orthodoxy. Remember in this context that the author of the Sarvadarśanasamgraha (and the author of most of chapter 16, once a separate composition), is himself a follower of a form of Mīmāmsā, called uttaramīmāmsā (p. 118 1. 4.283), brahmamìmāmsā (p. 128 1. 5.5; p. 399 1. 16.85; p. 414 1. 16.150151), śārīrakamìmāmsā (p. 117 1. 4.274-275; p. 405 1. 16.156; p. 458 1. 16.776). The Sarvadarśanasaṃraha itself calls ritual Mīmāṃsā pūrvamīmāṃsā (p. 118 1. 4.283; p. 267 1. 12.84), prācī mīmāms āa (p. 257 1. 12.3), adhvaramīmāmsāa (p. 58 1. 3.107). At the same time, it seems unlikely that he would consider himself to be a nasstika. Did he think of the ritual Mīmāmsakas as nāstikas?

Recall now that the passage beginning with the vocative nāstikaśiromane "Oh crest-jewel of the nāstikas!" is put in the mouth of a defender of the philosophy of Akṣapāda, i.e. in the mouth of a Naiyāyika. It does not therefore necessarily reflect the position of the author of the Sarvadarśanasamgraha (unlike the first occurrence of this compound, where it qualifies Cārvāka). All we can conclude from the use of

\footnotetext{
${ }^{20}$ There are serious doubts that the author of the Sarvadarśanasamgraha was actually called Mādhava; see Bronkhorst (forthcoming).

21 Sarvadarśanasaṃgraha p. 21.1.21-22: cārvākamatasya lokāyatam ity anvartham aparam nāmadheyam.

22 Ślokavārttika 5.10 (Saṃbandhākșepa) vv. 54-55.
} 
the word nāstika in the Sarvadarśanasamgraha is that its author looked upon the followers of Cārvāka as nāstikas and that the Naiyāyikas whose views are presented in the relevant chapter also looked upon ritual Mīmāṃsakas as nāstikas. Does this make sense?

The Sarvadarśanasamgraha is not the first text to suggest a link between ritual Mīmāmsāa and Lokāyata. A verse at the beginning of Kumārila's Ślokavārttika does the same ${ }^{23}$ :

For the most part Mīmāṃsā has, in this world, been turned into Lokāyata. This effort of mine is made to take it to the path of the asstikas.

Pārthasārathi comments as follows ${ }^{24}$ :

Mīmāṃsā, though not being Lokāyata, has been turned into Lokāyata by Bhartrmitra and others by accepting the incorrect position according to which there is no fruit, desired or not desired, of obligatory and forbidden [deeds] etc.

I have studied these and other texts elsewhere, ${ }^{25}$ and come to the conclusion that the Lokāyata here criticized is characterized by its rejection of rebirth and karmic retribution, or more simply: of "another world" (paraloka). The grammatical commentary called Káśika confirms this interpretation; it accounts for the words $\bar{a} s t i k a$ and nāstika under P. 4.4 .60 (astināstidișțam matị̣), in the senses "he who thinks "there is" and "he who thinks "there is not" " respectively, adding (Kâs I p. 448): na ca matisattāmātre pratyaya isyate, kim tarhi, paraloko 'sti iti yasya matih sa āstikaḥ / tadviparīto nāstikah /. In other words, an āstika is someone who believes there is another world, whereas a nasstika does not believe that there is another world. Early ritual Mīmāṃsā fitted the bill, so that the accusation of its proximity to Lokāyata makes sense. Kumārila Bhațta protested against this identification, and it is therefore ironic to see that the Naiyāyika in the Sarvadarśanasamgraha quotes from the work of this self-proclaimed āstika to support the position of the nāstikas.

Where does all this leave us? I think we can once and for all discard the notion that the sequence of chapters in the Sarvadarśanasamgraha reflects a hierarchical order. Furthermore, we have seen that in composing this text, use was sometimes made of more or less independently existing building blocks, which were at least to some extent adjusted to the role they had to play in the whole. This procedure can only be shown for certain portions of the text, but they raise the question whether a similar procedure was used elsewhere, too. Finally, the Sarvadarśanasamgraha divided its philosophies into two kinds: those that were unorthodox and needed to be refuted, and other ones that were presumably orthodox enough to be presented without judgment.

\footnotetext{
${ }^{23}$ Kumārila Bhaț̣a, Ślokavārttika, Pratijñā v. 10: prāyeṇaiva hi mīmāmnsā loke lokāyatīkṛtā / tām āstikapathe kartum ayam yatnah kṛto mayā //.

24 Pārthasārathi, Nyāyaratnākara p. 5: mīmāmsāa hi bhartrmitrāäibhir alokāyataiva satī lokāyatīkrtāa nityanișiddhayor ișțāniștạn phalam nāstītyādibahvapasiddhāntaparigraheneti ....

25 Bronkhorst (2007, pp. 122-128; 2016).
} 
Funding Open Access funding provided by Université de Lausanne.

Open Access This article is licensed under a Creative Commons Attribution 4.0 International License, which permits use, sharing, adaptation, distribution and reproduction in any medium or format, as long as you give appropriate credit to the original author(s) and the source, provide a link to the Creative Commons licence, and indicate if changes were made. The images or other third party material in this article are included in the article's Creative Commons licence, unless indicated otherwise in a credit line to the material. If material is not included in the article's Creative Commons licence and your intended use is not permitted by statutory regulation or exceeds the permitted use, you will need to obtain permission directly from the copyright holder. To view a copy of this licence, visit http:// creativecommons.org/licenses/by/4.0/.

\section{References}

Akamatsu, A. (2017). Doxography and perspectivism in premodern India: How is it possible to be neutral? Senri Ethnological Studies, 96, 159-174.

Aklujkar, A. (2017). History and doxography of the philosophical schools. In J. Ganeri (Ed.), The Oxford handbook of Indian philosophy (pp. 32-55). Oxford University Press.

Black, B., \& Patton, L. (Ed.). (2015). Dialogue in Early South Asian Religions. Hindu, Buddhist, and Jain traditions. Routledge.

Bronkhorst, J. (2007). Greater Magadha. Studies in the culture of early India. Brill. Indian reprint: Motilal Banarsidass, 2013.

Bronkhorst, J. (2016). Who were the Cārvākas? Revista Guillermo De Ockham, 14(1), 45-55.

Bronkhorst, J. (forthcoming). The Sarvadarśanasamgraha: One text or two? One author or two? Will appear in a Felicitation Volume.

Chakravarti, P. (1951). Origin and Development of the Sāmkhya System of Thought. Reprint: Oriental Books Reprint Corporation, 1975.

Cowell, E. B., \& Gough, A. E. (Trans.). (1892). The Sarva-Darśana-Samgraha or review of the different systems of Hindu philosophy by Madhava Āchārya (6th ed.). Chowkhamba Sanskrit Series Office, 1961. http://www.wisdomlib.org/hinduism/book/the-sarva-darśana-saṃraha/d/doc79743.html.

Deussen, P. (1908): Allgemeine Geschichte der Philosophie, mit besonderer Berücksichtigung der Religionen. Erster Band, dritte Abteilung: Die nachvedische Philosophie der Inder nebst einem Anhang über die Philosophie der Chinesen und Japaner. F. A. Brockhaus.

Doniger O'Flaherty, W. (1971). The origin of heresy in Hindu mythology. History of Religions, 10(4), 271-333.

Eltschinger, V. (2012). Apocalypticism, heresy and philosophy. In P. Balcerowicz (Ed.), World view and theory in Indian philosophy (pp. 29-85). (Warsaw Indological Studies, Vol. 5). Manohar. Reprint: Eltschinger (2014, pp. 35-92).

Eltschinger, V. (2014). Buddhist Epistemology as Apologetics. Studies on the history, self-understanding and dogmatic foundations of late Indian Buddhist philosophy. Österreichische Akademie der Wissenschaften (Philosophisch-historische Klasse, Sitzungsberichte, 851; Beiträge zur Kultur- und Geistesgeschichte Asiens, 81.)

Franco, E. (2011). Lokāyata. = BEH III, pp. 629-642.

Frauwallner, E. (1968). Materialien zur ältesten Erkenntnislehre der Karmamìmāmsāa . Wien: Kommissionsverlag der Österreichischen Akademie der Wissenschaften.

Frauwallner, E. (1992). Mādhavas Sarvadarśanasaṃgraha. Aus der 'Zusammenfassung aller Systeme': das System Śankaras. Nachgelassene Werke II: Philosophische Texte des Hinduismus. Hrsg. Gerhard Oberhammer und Chlodwig H. Werba. Verlag der Österreichischen Akademie der Wissenschaften. (Österreichische Akademie der Wissenschaften, philosophisch-historische Klasse, Sitzungsberichte, 588. Band; Veröffentlichungen der Kommission für Sprachen und Kulturen Südasiens Nr. 26.), pp. 176-223.

Goodding, R. A. (2002). The Treatise on Liberation-in-Life. Critical edition and annotated translation of the Jivvanmuktiviveka of Vidyāranya. Dissertation, University of Texas at Austin.

Halbfass, W. (1988). India and Europe. An essay in understanding. State University of New York Press. Hara, M. (1958). Nakulīśa-pāśupata-darśanam. Indo-Iranian Journal, 2, 8-32. 
Landau, H. G. (1953). On dominance relations and the structure of animal societies, III: The condition for a score structure. Bulletin of Mathematical Biophysics, 15(2), 143-148.

Larson, G. J., \& Bhattacharya, R. S. (Eds.). (2008). Encyclopedia of Indian Philosophies, 12. Yoga: India's philosophy of meditation. Motilal Banarsidass.

Maharaj, A. (Ed.). (2020). The Bloomsbury Research Handbook of Vedānta. London: Bloomsbury Academic.

Müller, F. M. (1899). The six systems of Indian Philosophy. Longmans, Green, and Co.

Nicholson, A. J. (2012). Doxography and boundary-formation in late medieval India. In P. Balcerowicz (Ed.), World view and theory in Indian philosophy (pp. 104-118) (Warsaw Indological Studies Series, Vol. 5). Manohar.

Nicholson, A. J. (2015). Dialogue and genre in Indian philosophy: Gītā, polemic, and doxography. = Black \& Patton (2015, pp. 151-172).

Pārthasārathi, Nyāyaratnākara. For the edition, see Ślokavārttika.

Pelissero, Alberto. 2020. The epistemological model of Vedantic doxography according to the Sarvadarśanasamgraha for the study of Indian Philosophy. Annali di Ca' Foscari. Serie orientale, 56, 245-272. https://doi.org/10.30687/AnnOr/2385-3042/2020/56/010.

Śābarabhāṣya of Śabara. Edited by Ganessaśāstrī Jośī. 7 volumes. Ānandāśrama Press. 1973-1984. See also Frauwallner (1968).

Sarvadarśanasaṃraha. (1) Sarva-darśana-saṃgraha of Sāyaṇa-Mādhava, edited with an original commentary in Sanskrit by ... Mahāmahopādhyāya Vasudev Shastri Abhyankar. (First published in 1924.) Third edition seen through the press by T. G. Mainkar. Poona: Bhandarkar Oriental Research Institute (BORI). 1978. (Government Oriental Series, Class A, No. 1.) (2) Edited, with Madhusūdana Sarasvatī's Prasthānabheda, by the Anandasrama pandits. Ānandāśrama Sanskrit Series (Poona), 1906, 1928, 1950. 3) Edited by Īśvarachandra Vidyāsāgara. Bibliotheca Indica (Calcutta), 1858.

Sharma, U. S. (1964). The Sarva-Darśana-Samgraha of Mādhavācārya. Edited with an exhaustive Hindi commentary, copious appendices and Anglo-Hindi introductions. Varanasi: Chowkhamba Vidyabhawan. (Vidyabhawan Sanskrit Granthamala, 113.)

Ślokavārttika of Kumārila Bhața. Edited, with the commentary Nyāyaratnākara of Pārthasārathi Miśra, by Swāmī Dvārikādāsa Śāstrī. Varanasi: Ratna Publications. 1978. (Ratnabharati Series-3.)

Strycker, N. (2014). The Thing with Feathers. The surprising lives of birds and what they reveal about being human. New York.

Tantravārttika of Kumārila Bhațta. See Śäbarabhāṣya.

Wilson, H. H. (1828). A sketch of the religious sects of the Hindus. Asiatic Researches, 16, 1-136.

\section{Abbreviations}

BEH Brill's Encyclopedia of Hinduism, ed. Knut A. Jacobsen, 6 vols., Leiden - Boston: Brill, 20092015.

Kāś Kāšikā by Vāmana \& Jayāditya, ed. Aryendra Sharma, Khanderao Deshpande, D. G. Padhye, Osmania University, Hyderabad, 1969-70, 2 vols.

P. Pāṇinian sūtra.

Publisher's Note Springer Nature remains neutral with regard to jurisdictional claims in published maps and institutional affiliations. 